\title{
The potential of carbon dioxide emission reductions in German commercial transport by electric vehicles
}

\author{
T. Ketelaer • T. Kaschub • P. Jochem • \\ W. Fichtner
}

Received: 11 December 2013/Revised: 24 March 2014/Accepted: 13 May 2014/Published online: 4 June 2014

(C) Islamic Azad University (IAU) 2014

\begin{abstract}
Climate change is a serious challenge of today. In order to reach the ambiguous mitigation scenarios for greenhouse gases, strong efforts are to be undertaken. Electric vehicles are seen as a potential mean to reduce emissions and energy import dependencies of most western societies. So far, the progress toward more electric vehicles in individual passenger transport is still slow. The objective to increase the share of electric vehicles of many national governments seems to be rather ambitious. In commercial transport, mileage is usually higher, trips are planned more precisely, and driving patterns are more regular than those of private vehicles. With these and other promising factors, we assume a high potential of electric vehicles in commercial transport. Therefore, we analyze in this paper the commercial transport in Germany and especially the large share of light commercial vehicles in order to make these potentials explicit. Based on German survey data, we analyze the heterogeneous German economic sectors with top-down statistical values like daily distance categories and bottom-up values like driving and parking behaviors. By way of example, German postal services are evaluated in detail, which leads to an electrification potential of between 60,750 and 105,550 vehicles. In case of "green" electricity for charging, postal services can avoid up to $882,000 \mathrm{t}_{\mathrm{CO}_{2}} / \mathrm{a}$, which is about $40-70 \%$.
\end{abstract}

\section{T. Ketelaer $(\bowtie)$}

Institute of Energy and Climate Research - Systems Analysis and Technology Evaluation (IEK-STE), Forschungszentrum Jülich, 52425 Jülich, Germany

e-mail: t.ketelaer@fz-juelich.de

T. Kaschub $\cdot$ P. Jochem $\cdot$ W. Fichtner

Chair of Energy Economics, Institute for Industrial Production (IIP), Karlsruhe Institute of Technology (KIT), Hertzstraße 16, 76187 Karlsruhe, Germany
Keywords Emission reduction potential - Electric mobility · Commercial transport in Germany - Sectoral analysis $\cdot$ Postal services

\section{Introduction}

Two main goals of the energy policy of the European Union are the reduction of carbon dioxide $\left(\mathrm{CO}_{2}\right)$ emissions and energy consumption. The objectives are ambitious with a reduction in $\mathrm{CO}_{2}$ emissions by $80 \%$ and energy savings of $30 \%$ until 2050 (compared to 2005) (European Commission 2011). Transport is responsible for about $23 \%$ of the European $\mathrm{CO}_{2}$ emissions. Many other sectors decreased their emissions in the last years, but the transport sector shows a significant increase (Eurostat 2013). About $75 \%$ of these $\mathrm{CO}_{2}$ emissions come from road transport (Eurostat 2013). So far, most policy instruments fail to reduce $\mathrm{CO}_{2}$ emissions in road transport in Europe (Bertoldi et al. 2011). Some studies identified high marginal abatement costs for $\mathrm{CO}_{2}$ emissions (ICCT 2013; IKA 2012). Transforming a part of the fossil fuel-based transport to electric mobility could reduce the emissions and energy resource demand, if considering an electricity generation based on "clean" energies (e.g., renewable energy resources).

Electric vehicles (EV) have a long history, but in the last century they were inferior to internal combustion engine vehicles (ICEV) concerning vehicle price, range, and refueling (Abt 1998). Both in private and in commercial transport, the ICEV outnumber all other means of transport (IEA 2011). In recent years, however, efforts to promote and develop competitive EV have gathered momentum. The reasons for this are manifold. On the one hand, there are political ambitions to counteract man-made climate change and to reduce the import dependency on oil and 
local emissions (European Commission 2011; German Federal Government 2009; Proff and Kilian 2012; UN 1998; van Dender 2009). On the other hand, the technological developments of components for EV are promising (Amjad et al. 2010; Brauner et al. 2012; IEA 2009; Köhler 2009; Pregger et al. 2012); especially, the developments of high voltage batteries (i.e., lithium-ion), the hybridization of ICEV, and fuel cell developments are worth mentioning. Additionally, the buildup of charging infrastructures (Kley 2011), standardization processes (Parker 2009; NIST 2009; Uslar et al. 2009, 2011), and numerous research activities promote the integration of and interfaces between transport, energy, and communication sectors (B.A.U.M. 2012; Pregger et al. 2012). Altogether, these efforts lead to a promising development of electric mobility. This is confirmed by several scenarios (Kay et al. 2013; Mock 2010; Pehnt et al. 2011), market potential analysis (Gnann et al. 2013; Pfahl et al. 2013), and government objectives (Proff and Kilian 2012). For 2020, the worldwide sales targets are expected to increase to eight million EV and plug-in hybrid electric vehicles (PHEV) (IEA 2011).

Looking at Germany, the objective of the federal government is to have a fleet of one million EV ( $2 \%$ of the vehicle fleet) in 2020 and of up to six million EV (>10\% of the vehicle fleet) in 2030 (German Federal Government 2010). The promotion in Germany is mainly accomplished by supporting research and development rather than directly subsidizing the purchase of $\mathrm{EV}$, as it is done in other countries. The process is accompanied by the German National Platform for Electric Mobility (NPE 2010, 2011, 2012) that represents all German stakeholders of automotive industry as well as related organizations, politicians, and research institutes. Nevertheless, in Germany, only 72 thousand EV have been registered at the beginning of 2013 out of 52,391 thousand of the whole fleet (42 million cars and other vehicles) (KBA 2013). This is not surprising if one considers that in 2012, the first EV by German original equipment manufacturers came on the market (e.g., Smart ED and Opel Ampera).

In particular, the present state of EV is analyzed in field tests, the acceptance in society is promoted, and integration of the involved sectors is supported (B.A.U.M. 2012; BMVBS 2011a; BMWi 2012). Even though today, the variable costs of EV are lower than those of ICEV, the fixed costs of EV are higher, and these vehicles lack in sufficient range and loading space [especially, this is true for battery electric vehicles (BEV)] (Ensslen et al. 2013; van Vliet et al. 2011). Hence, one needs to find fields of operation for EV, where high annual mileage comes together with low daily operation range, not to forget other parameters influencing the total cost of ownership (TCO) of the EV (Feng and Figliozzi 2012; Sharma et al. 2012). For example, an urban operational profile with high recuperation shares and regular charging possibilities during parking times is positive (Berg 1985). Based on these requirements, some parts of commercial transport seem to have best mobility characteristics, especially large shares of commercial passenger cars and light commercial vehicles $^{1}$ (LCV) below 3.5 tonnes gross vehicle weight (GVW).

However, there is a research gap analyzing commercial transport with respect to penetration potentials of EV. One reason for this gap is the insufficient data availability in most countries which impede to identify and evaluate mobility needs or behavior in commercial transport. In Germany, the data availability is becoming better through the mobility studies Kraftfahrzeugverkehr in Deutschland (KiD) 2002 and 2010 (KiD 2003, 2012a). The heterogeneousness of commercial transport in different sectors and subsectors increases the necessity for an accurate evaluation in order to give the right incentives for an efficient and accelerated market penetration of EV in commercial transport. So far, such an evaluation in respect of market potentials of electric LCV in commercial transport is missing in the literature (cf. "Studies on mobility patterns in German commercial transport" section).

Our objective in this contribution is therefore to analyze the German commercial transport and its sectoral characteristics in order to identify suitable subsectors, where electric LCV might be easily employed (i.e., a daily mileage considering range limits of EV and high annual mileages to compensate the high fixed costs). The resulting market potentials can be transferred in $\mathrm{CO}_{2}$ reduction potentials in German commercial transport by the electrification of LCV. In order to make the potentials more explicit, we evaluate the sector of postal services ${ }^{2}$ in detail. Heavy commercial vehicles of above 3.5 tonnes GVW are not considered within this research as no market-ready EV is available in Germany which achieves all relevant market needs. Additionally, our data sample, the study KiD 2010 (KiD 2012a), has the focus on commercial passenger cars and LCV. Due to this, the data basis is not sufficient for a meaningful evaluation of heavy commercial vehicles in German economic sectors.

In the following chapter "Materials and methods", we give an overview of German commercial transport and mobility studies. Then, we present our analyzing method for identifying the share of ICEV, which could be substituted by EV for each sector. In chapter "Results and discussion", we implement our method to German economic sectors before we show a detailed analysis for the postal services sector. Concluding, the corresponding $\mathrm{CO}_{2}$ emission reduction potential is indicated.

\footnotetext{
${ }^{1}$ Light commercial vehicles are defined excluding passenger cars. Light duty vehicles (LDV) include both LCV and passenger cars.

2 We use "postal services" for all delivery services such as courier, parcel, express, and postal services.
} 
Fig. 1 Distribution of LCV in different economic sectors in number of vehicles (KBA 2011)

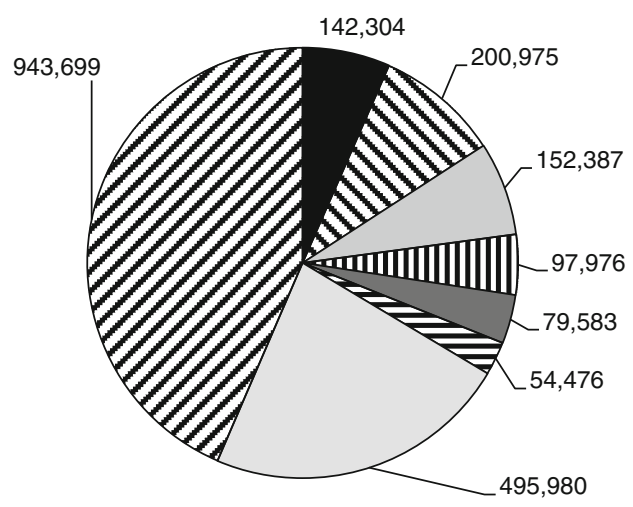

Manufacturing (C)

$\mathbf{\Delta}$ Construction $(\mathrm{F})$

$\square$ Wholesale and retail trade $(G)$

WI Transportation and storage $(\mathrm{H})$

Administrative services $(\mathrm{N})$

Public administration and defense $(0)$

$\square$ Other services (S)

$\square$ Other sectors
Our research shows a methodology for evaluating substitution potentials for BEV in commercial transport and the corresponding $\mathrm{CO}_{2}$ emission reduction potentials. In energy research, our results can be used for further works concerning the integration into the electricity system and its implications. Furthermore, it is a first step for politics to realize the potentials in commercial road transport and for companies to think about substituting their ICEV by EV. The research was done within the scope of the project iZEUS (01ME12013) at the Karlsruhe Institute of Technology (KIT) in 2013 with a view to enhance research, development, and practical demonstration in the fields of smart traffic and smart grid with one focus on commercial transport.

\section{Materials and methods}

\section{Commercial transport}

Commercial transport is complex because it combines the different forms of passenger transport and transport of goods (Steinmeyer 2004). Due to this, there is no uniform definition of the term commercial transport. The definition by Schwerdtfeger (1976) is used in most works related to commercial transport. It is denominated as the oldest accepted definition (Deneke 2004; Machledt-Michael 2000; Menge 2011; Steinmeyer 2004). Schwerdtfeger (1976) defines commercial transport as all trips executed by individuals within professional activities. Trips caused by personal interest and trips to and from work are not covered by this term. Commercial transport can be grouped or divided according to several characteristics. These may be weight (e.g., GVW), type of motor, vehicle registration, trip purpose, economic sector, or others.

\section{Shares of German commercial transport}

In Germany, 52.39 million vehicles (cars, LCV, motorbikes, and trucks) were registered as of January 1, 2013
(KBA 2013). Ninety percentage of these vehicles were privately owned. Ten percentage were commercially owned. The number of LCV amounted to 2.25 million of which $62.0 \%$ were commercially owned. ${ }^{3}$

The distribution of seven economic sectors [according to NACE Rev. 2 classification (Eurostat 2008)] with the most registered vehicles is shown in detail in Fig. 1. These sectors might be of special interest for further analysis as they have significant numbers of vehicles each. Most vehicles are registered in the sector other services (S) with nearly 500,000 vehicles. Further large sectors (140,000-200,000 vehicles) are the sectors manufacturing $(\mathrm{C})$, construction $(\mathrm{F})$, and wholesale and retail trade $(\mathrm{G})$. The sectors transportation and storage $(\mathrm{H}){ }^{4}$ administrative services $(\mathrm{N})$, and public administration (O) are smaller. Nevertheless, the sector transportation and storage $(\mathrm{H})$ is very interesting because the postal services are located here. In the postal services, most LCV are registered ("Specific sectoral analysis of postal services" section).

In spite of its little share on vehicles ownership, commercial transport generates more than one quarter of all driven kilometers in Germany (commercial transport: 428.04 billion $\mathrm{km}$, private transport: 161.97 billion $\mathrm{km}$ ). Therefore, in average a commercial vehicle is driven more kilometers per year than a private vehicle. This fact is somewhat relativized as $40 \%$ of the mileage in commercial transport is realized by privately owned vehicles (KiD 2012b). Commercially owned LCV are used for $92 \%$ of the mileage in commercial transport.

\section{German surveys}

Until the beginning of the last decade of the twenty-first century, not much was known about the characteristics of

\footnotetext{
${ }_{3}^{3}$ Many privately owned vehicles are used for commercial purposes vice versa.

${ }^{4}$ Transportation and storage $(\mathrm{H})$ includes commercial passenger transport, transport of goods, postal services, and storage activities.
} 
Table 1 Selection of transport surveys in Germany

\begin{tabular}{llll}
\hline Name of survey & Survey year & Focus & Source \\
\hline Fahrleistungserhebung & 2002 & Annual mileage & Hautzinger et al. (2005) \\
Mobilität in Deutschland (MiD) & 2002 and 2008 & Private transport & MiD (2010) \\
Mobilitätspanel (MOP) & Annual since 1994 & Private transport & Zumkeller et al. (2011) \\
Dienstleistungsverkehrsstudie & $2006 / 2007$ & Transport of service sector & BMWi (2008) \\
Güterverkehrsstatistik & 2010 & Freight transport & KBA (2010) \\
Kraftfahrzeugverkehr in Deutschland (KiD) & 2002 and 2010 & Commercial transport & KiD (2012a) \\
\hline
\end{tabular}

the German commercial transport (Wermuth 2006). Representative studies covering this part of German transport did not exist. In 2002, a series of transport surveys established a data basis of commercial transport that can be used for political decisions. Table 1 gives an overview of some of these empirical studies.

These studies focus on different parts of transport. The Fahrleistungserhebung (Hautzinger et al. 2005) investigates the annual mileage. The surveys Mobilität in Deutschland (MiD) (MiD 2010) and Mobilitätspanel (MOP) (Zumkeller et al. 2011) mainly contain observations on private transport. The survey Dienstleistungsverkehrsstudie (BMWi 2008) focuses on transport in services but the data are not available for public use. Finally, freight transport by heavy-load trucks is explored in the Güterverkehrsstatistik (KBA 2010).

For analyzing commercial transport with cars and LCV, we chose the survey of KiD 2010 (KiD 2012a). It focuses on transport of commercially owned motor vehicles and includes motorcycles, passenger cars, LCV, and a fraction of heavy-load trucks in Germany. Furthermore, the KiD 2010 is representative as it covers all German states and districts (NUTS 0-3). The survey was undertaken between November 2009 and October 2010. The participants were chosen by means of the resident concept. The selection of the participants was conducted on the basis of the Central Vehicle Register of the Federal Motor Transport Authority (KBA).

The datasets are classified using the methodology of the Federal Statistical Office (Destatis 2008). This methodology divides the German economy into 21 different economic sectors that are related to the international system of economic sectors of the United Nations (UN 2008). Among other characteristics, the survey queried the type of vehicle and powertrain, the type of the area where the vehicle is registered, the GVW, and the age of the driver. In total, the KiD 2010 contains 70,249 vehicle datasets. The participants had to fill in a driving log for each trip they realized on 1 day. The main results are single-trip datasets with starting and end time, distance, purpose, and parking place. Up to 205, different variables or characteristics are available for each trip. In addition, trip series were registered. With the help of two expansion factors, it is possible to calculate the total and the average vehicle stock in Germany.

\section{International transport studies}

Commercial transport is a relevant part of the transportation and storage sector worldwide (OECD 2012; RITA 2010; WTO 2012). Nevertheless, comprehensive surveys like the KiD studies with microdata in Germany seem not to be available for most other countries. The available data of national or international surveys focus mainly on private passenger transport. There are some national surveys available for central and northern Europe, but the survey design, methodology, and contents differ widely (Madre et al. 2007). At the European level exist the long-distance travel survey DATELINE (2004) and two surveys that focus on tourism (Eurostat 2012; Madre et al. 2007). For the USA, one survey series for daily household travel is available $(\mathrm{Hu}$ and Reuscher 2004; Santos et al. 2011). However, these surveys seem not appropriate for analyzing the commercial transport. Nevertheless, we assume different conditions in other countries, which are mainly driven due to regulation and the structure of the economy (European Commission 2012). Therefore, it is not possible to transfer the results of the German evaluation to other countries.

However, there exist studies that evaluate the potential EV market for commercial fleet operators, e.g., in the USA (Berg 1985). This study is based on nearly 600 interviews with fleet operators. It was already conducted in 1983 and observes potential markets concerning key factors such as miles travelled per day, industry type of application area, and vehicle type. Two other studies focus on the vehicle replacement of fleets based on data for the USA (Feng and Figliozzi 2012; Figliozzi et al. 2011). These studies are interesting, but they do not consider important restrictions for EV such as single-trip distances or parking times.

\section{Studies on mobility patterns in German commercial transport}

In Germany, transport research with the focus on mobility patterns in commercial transport started in the 1970s. The 
goal of this research has been to identify consistent clustering of commercial transport, e.g., to obtain homogeneous groups that help to analyze the flow of transport. This is done to obtain a better planning basis for future infrastructure projects, e.g., road construction or measures to reduce traffic in certain areas. Cluster analysis is a popular and meaningful method in these scientific papers (Deneke 2004; Hebes 2011; Schwerdtfeger 1976). Schwerdtfeger (1976) supports cluster analysis with a factor analysis, Deneke (2004) with a sequence alignment, and Hebes (2011) with a regression analysis. Others implement hypothesis testing (Schütte 1995) or support data analysis with the help of acceptance analysis (Hacker et al. 2011). The clusters obtained are supposed to define homogeneous groups of vehicles that differentiate from the other groups (Deneke 2004; Schwerdtfeger 1976). Each analysis uses different methods and databases.

Schwerdtfeger (1976) focuses on delivery services with an own data collection. He identifies the economic sector, retail space, and the number of full-time employees as most relevant information for clustering the driving behavior. $\mathrm{He}$ detects a general transport peak for delivery between 8 and 10 a.m. and a completion rate of $95 \%$ for all delivery orders until 4 p.m.

Schütte (1995) analyzes the business ventures of craft industry and their potential to reduce transport or to shift their main trips in time. He conducts an own survey and detects transport peaks between $7: 30$ and 8 a.m. and 3-4:30 p.m. Two-thirds of the vehicles have daily distances between 21 and $60 \mathrm{~km}$.

Deneke (2004) uses the survey data from the KiD 2002 (KiD 2003) study. He aggregates the different industry sectors into six groups and uses 23 different vehicle categories. His results show significant differences in the amount of daily trips and the times of driving. E.g., vehicles of the construction group have transport peaks in the morning and in the evening, whereas vehicles of the service group are used all over the day.

Hebes (2011) also bases his work on the KiD 2002 (KiD 2003) and additionally on the Dienstleistungsverkehrsstudie (BMWi 2008). He identifies four clusters. His main parameters are the number of trips, the number of connected trips, the daily distances, and the time of road use. The driving distances of the vehicles in these clusters range from 60 to $150 \mathrm{~km}$. The time of road use ranges from 80 min to more than $3 \mathrm{~h}$.

Hacker et al. (2011) use the KiD 2002 data (KiD 2003) as well. They identify four profiles. Their daily distances are between 35 and $125 \mathrm{~km}$. Most trips start between 7 and 8 a.m., whereas trips end in a wide range between 2 and 8 p.m. The ending time depends on the cluster.

These research results show the diversity of commercial transport and that there is a lack of studies for evaluation the possible penetration of electric mobility in the clusters of commercial transport.

\section{Requirements for electric mobility}

As the potential of commercial transport for electric mobility is analyzed, requirements for electric mobility must be taken into consideration. The development of electric mobility is manifold because it influences the automotive, battery, electric, and communication industry as well as the transport infrastructure (e.g., charging stations). Besides further developments in all these industries, the main requirements for electric mobility derive from the vehicles' owner and driver. The main technical and economic aspects are as follows:

- Driving range,

- charging infrastructure and fleet management,

- profitability determined by TCO,

- emissions, and

- other framework conditions.

The driving range is determined by the average consumption and the battery energy content (capacity) for pure electric driving. The barriers consist in the low energy density of the battery and the high battery price. The battery density is multiple times lower than the energy density of petrol fuel and, therefore, increases the vehicle weight and decreases the payload space. Installing a range extending internal combustion in addition to the electric motor, the range limit is eliminated. This is, however, associated with increasing costs and (partly) a loss of emission free driving.

The second requirement is a sufficient available charging infrastructure. The accessibility to places with charging infrastructure influences the usability of BEV and the operation costs of PHEV. An alternative is to set up battery switching stations. This might be an alternative especially for local bus companies (Kaschub et al. 2012). Limited charging possibilities for an EV fleet require a complex fleet management with integrated charging management.

A specific comparison of the profitability of the alternative vehicle concepts (ICEV, BEV, and PHEV) requires a TCO analysis. The compensation of the higher investment of BEV or PHEV might be compensated by lower operation costs, subsidies, or tax benefits.

Lower emissions from traffic will gain more relevance in future for drivers and companies. Some cities already have areas with limited access for some vehicles with high emission and congestion charges are tested or in discussion. Therefore, emission limits for vehicles are going to gain more relevance. In Europe, this is already true for local emissions (e.g., by the European Regulation 715/2007) and for greenhouse gas (GHG) emissions (e.g., 
European Regulation 443/2009). Though BEV are driven locally emission free, the global emissions (well to wheel) could be determined by electricity emission factors.

Additionally, certain framework conditions have to be met. The acceptance of BEV in the society and by the user as well as the pleasure for the driver can influence the buying process (Ensslen et al. 2013). Furthermore, financing models like leasing contracts play an important role for the development of electric mobility. Consideration of all these factors would go beyond the scope of our analysis. Furthermore, the analysis focuses on BEV and not on PHEV as the observed restricting criteria have a stronger influence on the substitution potential and their emission reduction potential is higher. Furthermore, first results of PHEV charging behavior show that charging is often omitted for commercial vehicles due to missing incentives (Ligterink et al. 2013).

\section{Methodology}

To our knowledge, there is a lack of research considering the restrictions of EV for commercial transport and the question of possible vehicle replacement from conventional vehicles to EV. In the following, we give an outline of the developed methodology.

\section{Criteria for our potential analysis}

In the following, we focus on the substitution potential analysis of ICEV by BEV. We base on the results of the recent research of commercial transport ("Studies on mobility patterns in German commercial transport" section) and the requirements for electric mobility ("Requirements for electric mobility" section). An estimation of the substitution potential of ICEV by BEV and the thereby linked emission reductions can be done with the following two steps:

1. General sectoral analysis to identify the main relevant economic sectors and specify their characteristics. Criteria analyzed are number of vehicles, average mileage, operational profiles, daily trips, and parking times at night.

2. Specific sectoral analysis of selected economic sectors with more detailed criteria, especially detailed parking places and times. The objective is to roughly identify potential EV shares. With this result, an estimation of the emission reduction potential can be done.

In a first step, the relevance of the economic sectors is identified by the number of vehicles in the sector and the daily and annual mileages. Daily mileage is restricted by the BEV operation range and charging infrastructure available. The daily distance is presented with its arithmetic mean value, share of kilometer classes, median, and first and third quartile. Annual mileage helps to estimate the cost effectiveness. Information about the general operation times and shares is received by an operational profile. It is generated with a time resolution of a quarter of an hour and may little overestimate the driving times. The operational profiles allow an identification of peak operation times and main parking times (e.g., during the night). First estimations of operation times and sufficient charging times can be done based on these data.

The second step adds criteria to the analysis: the number of daily trips, the parking times, and the parking places. All these criteria are helpful in identifying prohibitive conditions for BEV, especially concerning charging times and operation distances. A further differentiation between the vehicles' mobility use can be made by analyzing the operation area based on district classes and by a further temporal investigation based on different weekdays. A temporal analysis based on different days of the week is often done with groups of weekdays (e.g., workdays and weekend).

Berg (1985) examined further criteria which are not considered here, as the database is not detailed enough or the relevance for a sectoral analysis is not given. First parameter is the fleet size of a company, which influences the possibility to substitute single trips by other vehicles of the fleet. Second parameter is the vehicle size, which we only consider by classing into passenger cars and LCV. A further differentiation of car segments is neglected as well as high-speed requirements, which in general correspond to long trips.

All these criteria are more relevant in a particular vehicle investment decision, which is not defined and analyzed in this paper as we focus on whole group of vehicles and not on certain vehicles. Hence, we do not include a TCO analysis. Results for TCO can be found, e.g., in Al-Alawi and Bradley (2013) and Plötz et al. (2012). This paper does not consider behavioral change in the use of vehicles, too, because the survey design of the $\mathrm{KiD}$ does not consider this issue.

\section{Approach}

Our analyses are mainly based on the German survey data of $\mathrm{KiD} 2010$ (KiD 2012a). ${ }^{5}$ We combine the separated vehicle and trip data to time-step-based mobility tables and evaluate the data with standard statistical analyzing tools. Therefore, we take the starting and ending time of each trip to one of the 96 quarters of a day. The time between these two quarters (from starting time to ending time of the trip)

\footnotetext{
5 The survey data are available in different data formats. We use the SPSS files and the SPSS software for evaluation.
} 
is labeled "mobile," and outside time steps are labeled "parking." Next, we transfer the trip-based data to a vehicle-based table.

For further analysis of the parking places over time, we add additional information about origin place and terminus of each trip to each time interval between the trips. As the data for the survey are collected on 1 day for each car, the place of parking after the last trip sometimes differs from the origin of the first trip in the morning. To get a consistent database for 1 day, we allocate the parking place after the last trip to the whole period between the last trip and the first trip of the day. For vehicles that are not used the whole day, the actual parking place remains unclear; therefore, we assigned the given value of the usual parking place to these vehicles.

The spatial operation area is depicted by the method of the German Federal Institute for Research on Building, Urban Affairs, and Spatial Development (BBSR). It considers four different region types based on population density (BBSR 2011). For the temporal analysis of the weekdays, we combined the similar weekdays of Tuesday to Thursday and analyzed Saturday separately. Friday and Monday have slightly different profiles than the other working days. On Sunday, commercial mobility is low. Additionally, the number of datasets for these days is low, so they are not considered in the analyses.

The calculation of parking duration between the trips is calculated by simple subtraction. The annual mileage is calculated based on the information about the mobility behavior from the day of the interview, additional information (e.g., region, date), and the expansion factor (KiD 2012a). All other information and classifications (e.g., the daily mileage) are directly given in the datasets.

\section{Results and discussion}

In the following, we first describe the results of our general analysis of economic sectors ("General sectoral analysis" section). Second, we focus on the example of postal services ("Specific sectoral analysis of postal services" section). We continue to determine a substitution potential of these ICEV by BEV and the corresponding $\mathrm{CO}_{2}$ Emissions Reduction Potential in "BEV substitution and $\mathrm{CO}_{2}$ emissions reduction potential for LCV in postal services" section.

\section{General sectoral analysis}

The data of the KiD 2010 (KiD 2012a) can be divided into the 21 economic sectors used by the European Commission and the German Federal Statistical Office (Eurostat 2008). The classification is based on information given by the owners of the vehicles. In most of the different economic sectors, a high percentage of vehicles is driven $<150 \mathrm{~km}$ per day (Fig. $2 \mathrm{a}$ ). ${ }^{6}$ In five sectors [mining and quarrying $(\mathrm{B})$, transportation and storage $(\mathrm{H})$, professional, scientific and technical activities (M), ${ }^{7}$ education $(\mathrm{P})$, and activities of extraterritorial organizations and bodies $(\mathrm{U})]$, the share of vehicles that drive more than $150 \mathrm{~km}$ a day is higher. The box plots in Fig. 2b show the second and third quartile. The median is the boundary between these quartiles. It seems that most trips are below $100 \mathrm{~km}$. In this figure, it can be seen that only in the two sectors-mining (B) and education (P) - distances of more than $150 \mathrm{~km}$ are driven with more than $50 \%$ of their vehicles.

For the general sectoral analysis based on the annual mileage performance, the average distance of single trips, and the parking time of the vehicle overnight and day, we use the sectors manufacturing (C), construction (F), wholesale and retail trade $(\mathrm{G})$, transportation and storage $(\mathrm{H})$, public administration $(\mathrm{O})$, and health services (Q) only. These sectors seem to be interesting because they fulfill following criteria:

- High number of registered vehicles,

- high share of vehicles driving inside cities, and

- heterogeneity of the mobility profiles.

The average annual mileage performance of all passenger vehicles in 2009 was $14,250 \mathrm{~km}$. Commercial vehicles including trucks were driven $24,960 \mathrm{~km}$ on average (BMVBS 2011b). LCV in the sectors manufacturing $(C)$, wholesale and retail trade $(G)$, and health services (Q) have an annual mileage performance that is in between those two values. The sector transportation and storage (H) has the highest annual mileage (even more than the average of commercial vehicles including trucks in total), whereas the public administration sector $(\mathrm{O})$ has an annual mileage that is far below (Table 2, column 4). Therefore, an economic operation of BEV for most of its vehicles is not probable in this sector. Only for vehicles with a high annual mileage and without an outstandingly high daily mileage (no more than $\geq 150 \mathrm{~km}$ ), an economic operation seems possible.

The LCV of the examined sectors are driven $<30 \mathrm{~km}$ in single trips on average, except the LCV of the transportation and storage sector $(\mathrm{H})$ (Table 2, column 6). In this sector, the average single-trip mileage amounts to $50 \mathrm{~km}$.

\footnotetext{
${ }^{6}$ One hundred and fifty kilometers is chosen here for being a range that can be reached by some current BEV, e.g., Smart E-Drive and Citroen C-Zero.

7 Professional, scientific, and technical activities (M) include legal advice, tax consulting, accountant activities, consulting activities, architects, research and development activities, market research and advertising, and other freelance work.
} 
Fig. 2 Typical daily mileage of vehicles in different economic sectors

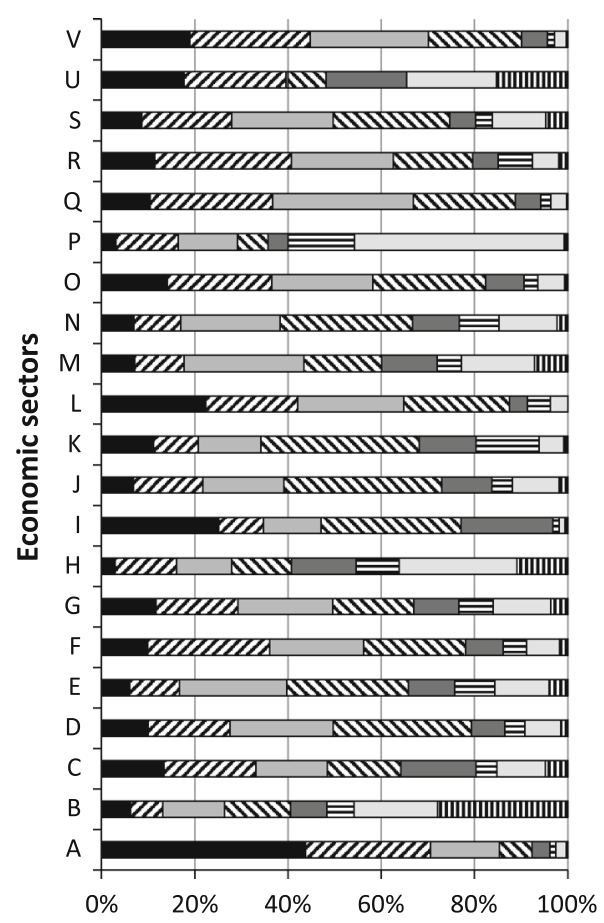

Share of all driven kilometers in the sector

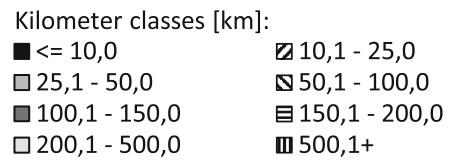

(a) Share of kilometer classes in percentage

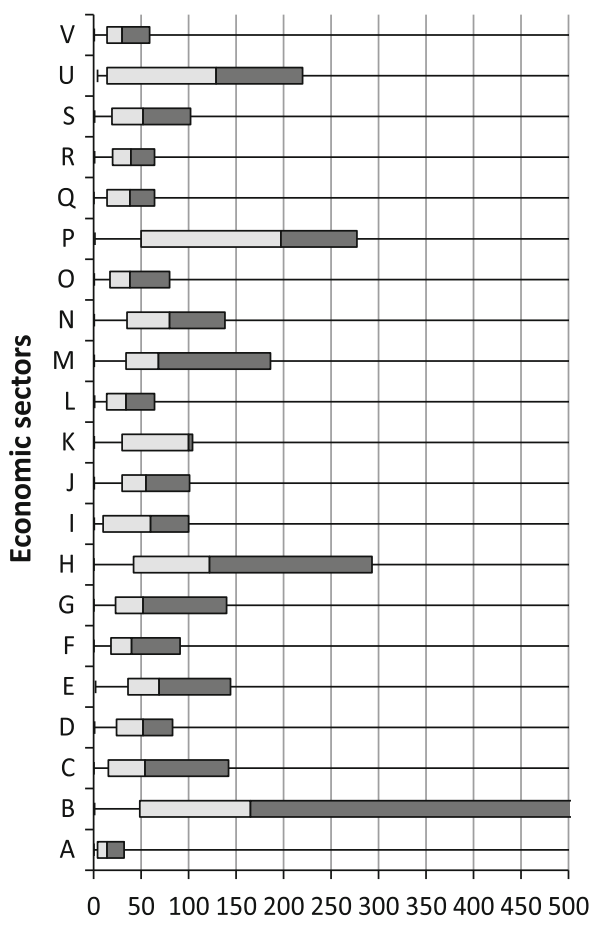

Daily driven mileage in kilometer

$\square$ 2nd quartile $\square$ 3rd quartile

(b) Quartiles of the daily driven mileage

Table 2 Characteristics of LCV in selected economic sectors (average values)

\begin{tabular}{|c|c|c|c|c|c|c|c|}
\hline \multirow{2}{*}{$\begin{array}{l}\text { Economic sector } \\
\text { Unit }\end{array}$} & \multirow{2}{*}{$\begin{array}{l}\text { Number of vehicles }{ }^{\mathrm{a}} \\
\text { Thousand }\end{array}$} & \multirow{2}{*}{$\begin{array}{l}\text { Share of mobile vehicles } \\
\%\end{array}$} & \multirow{2}{*}{$\begin{array}{l}\text { Annual mileage } \\
\text { Kilometer }\end{array}$} & \multirow{2}{*}{$\begin{array}{l}\text { Daily mileage } \\
\text { Kilometer }\end{array}$} & \multicolumn{2}{|c|}{ Single daily trips } & \multirow{2}{*}{$\begin{array}{l}\text { Parking time } \\
\text { at night } \\
\text { Minutes }\end{array}$} \\
\hline & & & & & Number & Kilometer & \\
\hline $\mathrm{C}$ & 200.8 & 61.4 & 15,235 & 91.8 & 7.6 & 27.4 & 461.2 \\
\hline $\mathrm{F}$ & 662.4 & 67.7 & 13,292 & 74.0 & 4.5 & 25.8 & 441.5 \\
\hline G & 228.5 & 60.0 & 18,431 & 114.9 & 10.4 & 28.2 & 503.8 \\
\hline $\mathrm{H}$ & 180.7 & 73.1 & 32,432 & 165.7 & 42.1 & 50.0 & 509.3 \\
\hline $\mathrm{O}$ & 69.8 & 70.2 & 9,247 & 48.4 & 13.0 & 12.9 & 449.9 \\
\hline Q & 23.9 & 77.5 & 16,719 & 81.1 & 17.7 & 18.5 & 532.2 \\
\hline
\end{tabular}

Economic sectors: C: manufacturing; F: construction; G: wholesale and retail trade, repair of motor vehicles and motorcycles; H: transportation and storage; O: public administration and defense, compulsory social security; Q: human health and social work activities

a Numbers from KiD 2010 study multiplied with the expansion factor

So, the single daily trip mileage is below the expected barrier for current BEV of $150 \mathrm{~km}$ (Table 2, column 5). Thus, the batteries of the vehicles can be charged after a single trip if the next parking time is long enough and a charging infrastructure is available. The analysis of the parking time at night reveals an average between 7:20 and $8: 45 \mathrm{~h}$ for all of these sectors (Table 2, column 7). Due to this, there is enough time to recharge an EV overnight at a normal household socket, ${ }^{8}$ in most cases. If a special charging equipment is installed (e.g., Mode-3-Charging), charging can be much faster.

\footnotetext{
$\overline{8}$ In Germany, household sockets have a (theoretical) maximum power of $3.7 \mathrm{~kW}$ based on $16 \mathrm{~A} / 230 \mathrm{~V}$, which leads to about $7.5 \mathrm{~h}$ for a fully charge of a battery capacity of $27 \mathrm{kWh}$.
} 
Fig. 3 Share of mobile LCV in every quarter of an hour of a day over all days of the week in the economy sectors

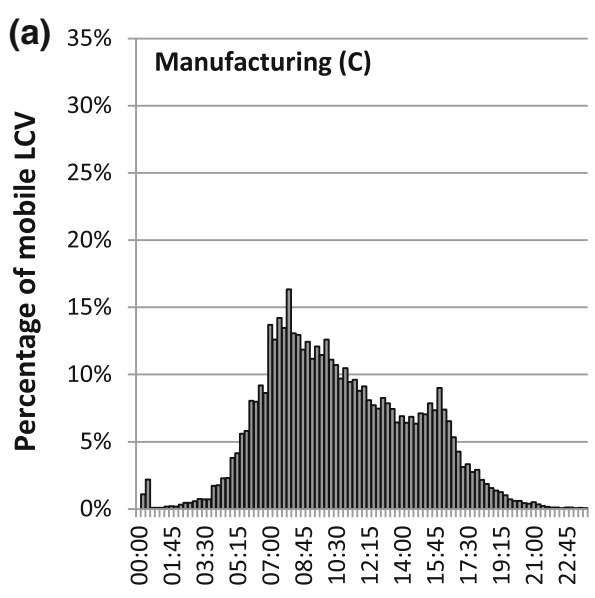

(c) $35 \%$ Wholesale and retail trade; repair of
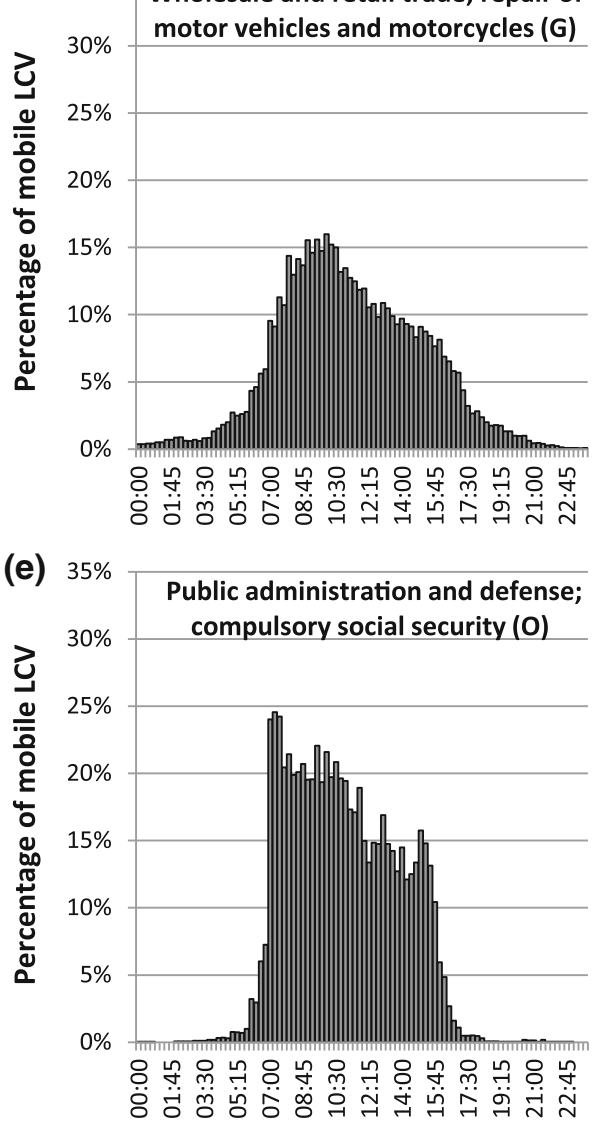
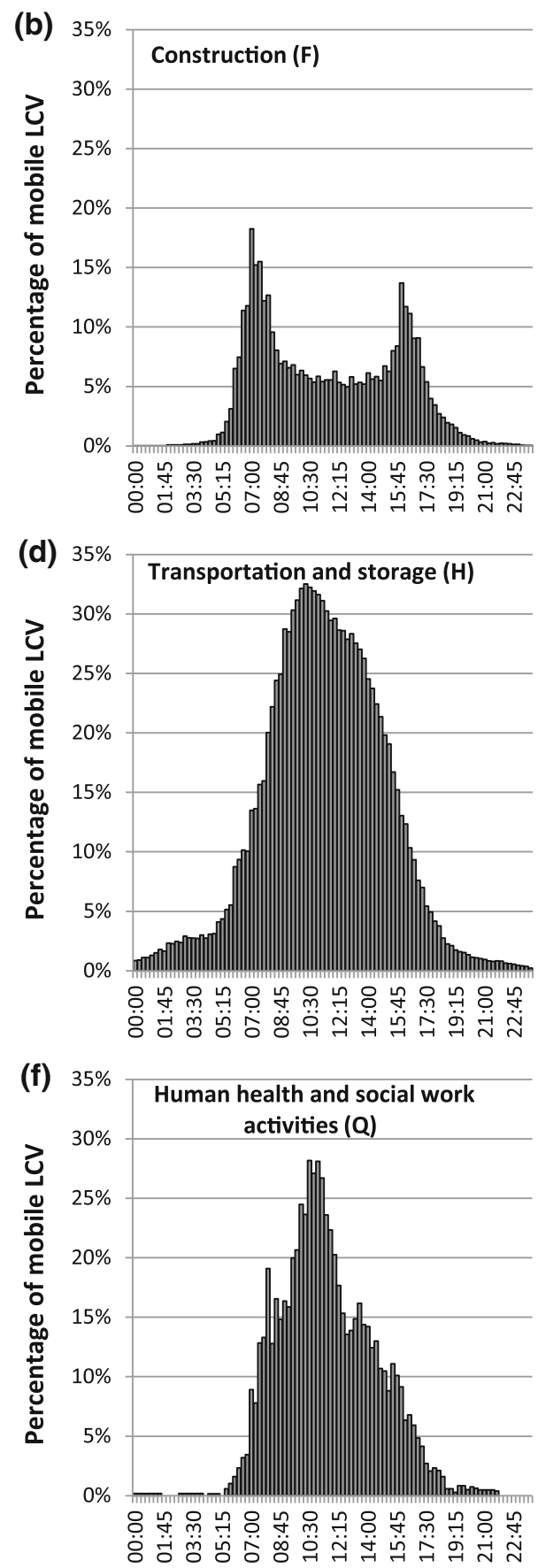

When considering the numbers of LCV from the KiD 2010 study (Table 2, column 2), which is based on the answers given in the survey by the drivers, the sector construction $(\mathrm{F})$ has by far the highest number, followed by sector wholesale and retail trade $(\mathrm{G})$, manufacturing $(\mathrm{C})$, and transportation and storage $(\mathrm{H})$. These numbers differ from those in Fig. 1 that is based on data of the KBA (e.g., construction (F): 662,400 vs. 200,975 LCV). Obviously, a large number of the vehicles are operating in a sector that differs from the sector they are registered in. As we are more focused on the real driving behavior of vehicles, we use the data of the KiD (KiD 2012a).

Figure 3 shows the operational profiles of the six selected sectors. The profile of the sector construction (F) (10,031 observed vehicles) has a distinctive morning and evening peak. In the morning, $15-20 \%$ of the vehicles are mobile and in the evening $10-15 \%$. The percentage of mobile LCV between these peaks is about $5 \%$. A possible explanation might be that vehicles of the construction sector $(\mathrm{F})$ are used for the trip to certain 
construction areas and to return from them in the evening.

The wholesale sector (G) (3,583 observed vehicles) only has one peak between 8 and 11 a.m. The peak is followed by a slight decrease in the mobility rate until 4 p.m. After 4 p.m., the decrease is faster. At the peak, around $15 \%$ of the LCV are mobile. The profile of the manufacturing sector $(\mathrm{C})$ is similar to the wholesale sector.

The transportation and storage sector $(\mathrm{H}) \quad(3,282$ observed vehicles) has only one peak in its operational profile as well. In contrary to the wholesale and retail sector $(\mathrm{G})$, the share of mobile vehicles is almost twice. Between 8 a.m. and 2 p.m., more than $20 \%$ of the LCV are mobile and the peak even reaches more than $30 \%$.

The sector public administration $(\mathrm{O})$ has a high share of mobile vehicles between 7 a.m. and 3:45 p.m. It is clearly delimited from the remaining time of the day without mobility. The peak of mobile vehicles is at 7:15 a.m. with almost $25 \%$. This share decreases until 3:45 p.m.

The profile of the sector health services (Q) (386 observed vehicles) has the form of a pyramid. A single peak can be seen between 10:30 and 11:00 a.m. It reaches almost $30 \%$. Before and after the peak, the mobility rate increases and decreases rapidly, respectively.

In general, vehicles are not used during the night. The mobility rate is lower than $2 \%$ in all six sectors between 7 p.m. and 5 a.m.

The described results show considerable differences in mobility behavior throughout all criteria. Therefore, a further differentiation of the economic sectors for analyzing the commercial traffic is reasonable. The results obtained substantiate the differences in the results of several of the traffic studies introduced in "German survey" and "International transport studies" sections.

Specific sectoral analysis of postal services

The reasons for choosing postal services by way of example are promising key characteristics of the sector transportation and storage $(\mathrm{H})$, which contains most of the vehicles operating in the postal services. These promising characteristics are low mileage for daily $(<150 \mathrm{~km})$ and high mileage for annual time horizons, which were evaluated in step one ("General sectoral analysis" section). Postal services are chosen for being an interesting sector of the economy with many trips inside cities. Hence, there might be a potential for substituting ICEV with BEV.

A specific analysis of the LCV operating for the postal services is possible by a specifying variable in the KiD 2010 (KiD 2012a) for this subsector. This attribute applies to $2,699 \mathrm{LCV}$. A total of 1,954 of these 2,699 vehicles belong to the sector transportation and storage $(\mathrm{H})$. The remaining vehicles are registered in other sectors. With

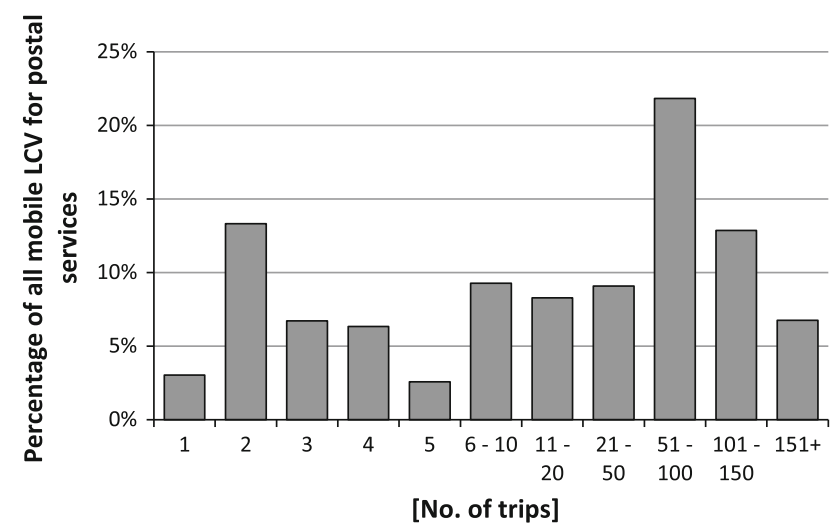

Fig. 4 Share of number of daily trips of LCV for postal services

Table 3 Average duration of the different parking times of $\mathrm{LCV}<3.5 \mathrm{t}$ operating for postal services

\begin{tabular}{llll}
\hline & $\begin{array}{l}\text { Parking at } \\
\text { night } \\
\text { Minutes }\end{array}$ & $\begin{array}{l}\text { One day time } \\
\text { parking } \\
\text { Minutes }\end{array}$ & $\begin{array}{l}\text { Several times } \\
\text { daytime parking } \\
\text { Minutes }\end{array}$ \\
\hline Arithmetic mean & 533.5 & 225.6 & 121.5 \\
Median & 510.0 & 135.0 & 75.0 \\
\hline
\end{tabular}

extrapolation, this results in about 151,867 LCV operating in the postal services in Germany.

First of all, because of its intersectoral structure, we repeat the general analysis for the postal services (step one). Then, we extend the analysis by the criteria explained (step two). Both steps are explained in "Criteria for our potential analysis" section.

Light commercial vehicles (LCV) in the postal services are driven $30,603 \mathrm{~km}$ on average every year. The average daily mileage is $141.5 \mathrm{~km}$. The analysis of regional differences by separating the four district classes according to the methodology described in "Approach" section shows minor differences. Previously, we had expected that greater daily distances would be observed in rural areas compared to densely populated surroundings such as cities or suburbs. This was not confirmed. In general, we can say that the regarded barrier of $150 \mathrm{~km}$ daily driven kilometers is not exceeded by at least $65 \%$ of all the registered postal services LCV in all registration communities. Thus, almost two-thirds of these vehicles could drive all day long without being recharged. The high annual mileage can make an economic operation possible. Therefore, a more detailed analysis is necessary and useful.

Figure 4 shows the number of daily trips of LCV in the postal services. It is remarkable that a high share $(>40 \%)$ of the observed vehicles is used for more than fifty trips a day. This proves the assumption that vehicles used for postal services have many trips per day. Obviously, all trips between major stops for delivering goods were seen as 
Fig. 5 Share of mobile LCV in every quarter of an hour of a day of LCV operating for the postal services

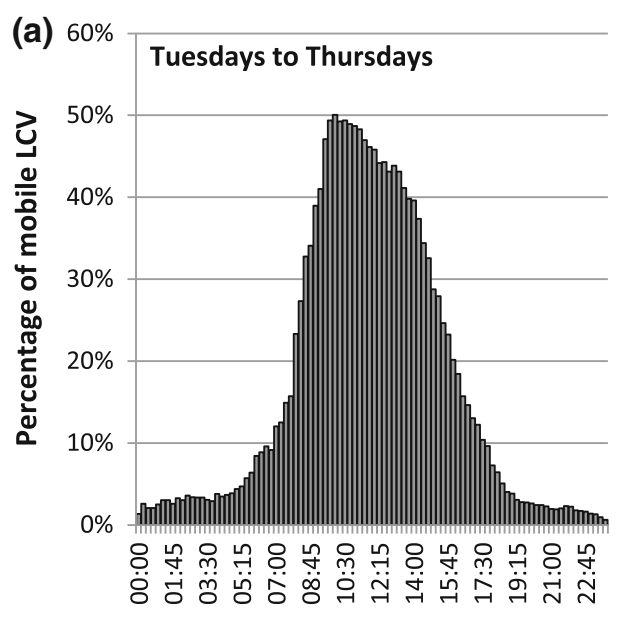

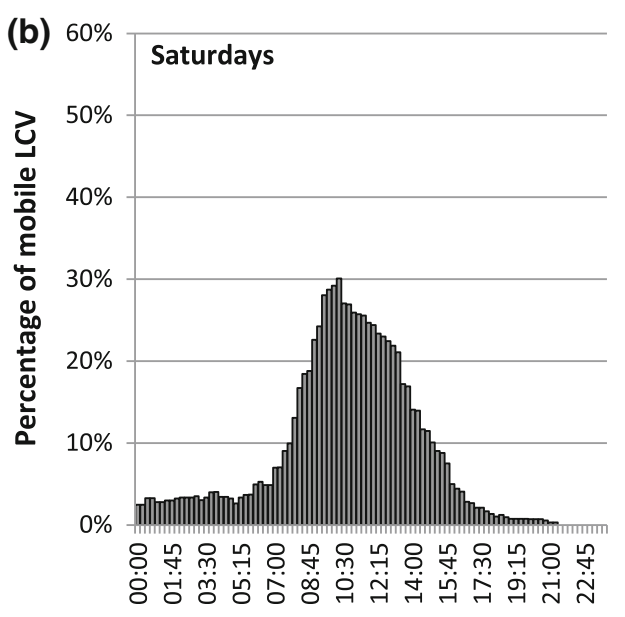

single trips. More than $60 \%$ of the vehicles are used for more than 10 trips a day. The share of LCV that are used for one to five trips daily varies between 2 and $14 \%$; especially for LCV, a high number of starts and stops seem to be favorable for $\mathrm{EV}$, because recuperation of braking energy can be used regularly. So the efficiency of the LCV increases, and the operation costs decrease.

Table 3 lists the different parking categories (parking at night, during the day once, and several times) by the arithmetic mean and the median. On the average, the LCV park at night for almost $9 \mathrm{~h}$ and more than half (median) of the LCV (if BEV) could be fully charged at a normal household socket during this time. Even $87 \%$ of the vehicles park at night for at least $6 \mathrm{~h}$. Hence, a very high number of vehicles have the possibility to get charged at least $80 \%$ of the battery at night. During the day, parking times are shorter; therefore, only partial charging at a normal household socket can be realized. Nevertheless, with fast charging, ${ }^{9}$ the parking time during the day is in many cases sufficient for full charging.

In Fig. 5, the aggregated profile for the weekdays Tuesday to Thursday (a) and the profile for Saturdays (b) are shown. The profiles are similar to the profile of the transportation and storage sector $(\mathrm{H})$ in Fig. 3 .

Both figures have a single peak, but the share of mobility on Saturdays is lower. During the week (Tuesday to Thursday), the maximum of mobile vehicles reaches more than $50 \%$ between 10 and 10:15 a.m. On Saturdays, the peak reaches only slightly more than $30 \%$. Thus, around $60 \%$ of the mobility rate of working days is reached. According to the profiles, only very few vehicles are mobile between 6 p.m. and 6 a.m. Therefore, charging at night would not be a barrier for most of the LCV.

Figure 6 illustrates the parking places of the LCV in postal services. Thereby, a good analysis of charging

\footnotetext{
$\overline{9}$ With a fast charging system (22 kW, mode $3 \mathrm{AC}$ charging), about $75 \mathrm{~min}$ is needed for full charging.
}

potential is possible. The figure considers all days of the week. Almost $40 \%$ of the LCV are not moved during the day. At night, more than $40 \%$ of the vehicles park at the own company. By including transition points and private places as potential charging places, up to $60 \%$ of the LCV might have a charging possibility at night. The share of vehicles parking at customer households overnight seems to be rather high. During the day, the share of vehicles parking at the own company is above $27 \%$. Hence, there exists a charging possibility during the day for these LCV, too.

\section{BEV substitution and $\mathrm{CO}_{2}$ emissions reduction potential for LCV in postal services}

When considering the previous results, we can give a first estimation of the substitution potential for LCV in postal services. It is not possible to combine all criteria for single vehicles at once, as mileage of 1 day as questioned in the survey is not sufficient as average (maximum) mileage of a vehicle. Therefore, the total substitution potential cannot be calculated directly. However, we calculate the minimum and maximum potential boundaries on basis of none or full intersection of all considered criteria. The maximum potential is given by the lowest single value. The minimum potential is given by no intersection of the three criteria. ${ }^{10}$

Table 4 gives an overview of criteria to calculate the substitution potential of ICEV by BEV in postal services for LCV. We use a minimum and a maximum estimation as possible scenarios. The maximum potential of the maximum estimation is $69.5 \%$ and for minimum estimation is $40 \%$. Hence, the substitution potential is up to 60,750 or $105,550 \mathrm{BEV}$ in the postal services sector. In case that the available mileage or the available charging infrastructure improves, the substitution potential will rise. As the

\footnotetext{
${ }^{10}$ No intersection is given by subtracting the single values by $100 \%$.
} 
Fig. 6 Operational profile of LCV of the postal services including parking places

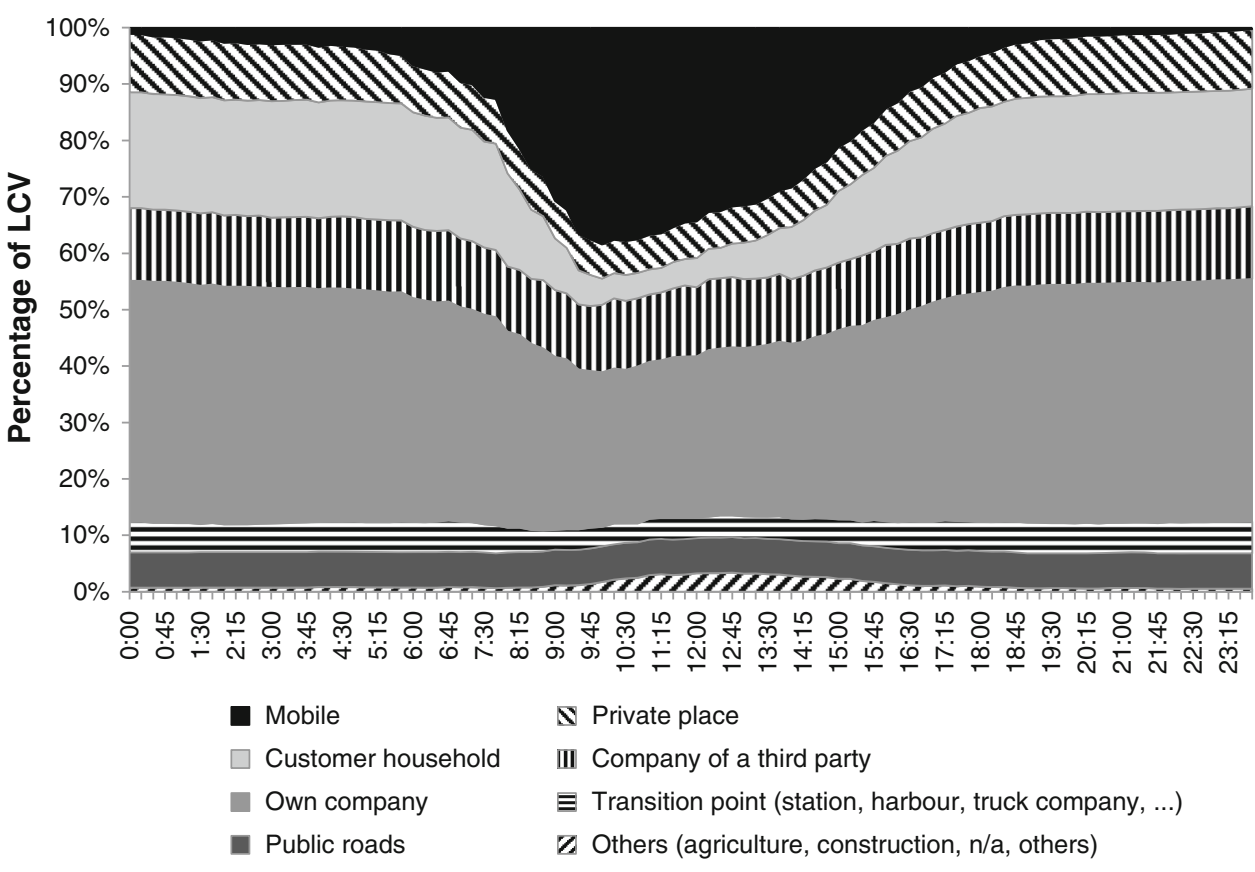

Table 4 Criteria for estimation of BEV substitution potential for the postal services

\begin{tabular}{|c|c|c|c|c|}
\hline \multirow[t]{2}{*}{ Criteria } & \multicolumn{2}{|c|}{ Minimum estimation } & \multicolumn{2}{|c|}{ Maximum estimation } \\
\hline & Value & $\begin{array}{l}\text { Share } \\
(\%)\end{array}$ & Value & $\begin{array}{l}\text { Share } \\
(\%)\end{array}$ \\
\hline Daily mileage & $\leq 100 \mathrm{~km}$ & 58.0 & $\leq 150 \mathrm{~km}$ & 69.5 \\
\hline $\begin{array}{l}\text { Parking time at } \\
\text { night }\end{array}$ & $\geq 8 \mathrm{~h}$ & 64.0 & $\geq 2 \mathrm{~h}$ & 98.0 \\
\hline $\begin{array}{l}\text { Charging } \\
\text { possibility }\end{array}$ & $\begin{array}{l}\text { Own } \\
\text { company }\end{array}$ & 40.0 & Everywhere & 99.0 \\
\hline $\begin{array}{l}\text { Minimum } \\
\text { potential }\end{array}$ & & 0.0 & & 66.5 \\
\hline $\begin{array}{l}\text { Maximum } \\
\text { potential }\end{array}$ & 60,750 & 40.0 & 105,550 & 69.5 \\
\hline
\end{tabular}

average annual mileage of the LCV is above $30,000 \mathrm{~km}$, this criterion does not limit the potential. ${ }^{11}$

The calculated potential gives a basis for an estimation of the reduction of $\mathrm{CO}_{2}$ emissions. We undertake this analysis for a whole country. In principle, this approach could be used to identify $\mathrm{CO}_{2}$ emission reduction potentials of companies or cities, which are a recent research issue (e.g., Liao et al. 2013). Our calculation is based on the difference of $\mathrm{CO}_{2}$ emissions from a conventional to electric $\mathrm{LCV}$. The emissions for conventional vehicles are given directly by the manufacturers on basis of the fuel needed and standardized driving cycles for the specific fuel consumption. For the electric LCV, the emissions depend on

\footnotetext{
11 Annual mileages of single vehicles cannot be calculated properly. They are calculated based on the 1 day survey.
}

the specific energy consumption and the electricity used. The conversion of primary energy into electricity determines the emission factor for electricity. In most countries, a mix (coal, gas, fission, and renewable energy sources) is applied. Electricity from coal has high emission factors (Heinrichs 2013; Walvekar and Gurjar 2012). The reduction potential of $\mathrm{CO}_{2}$ emissions is in this worst case not given. The best case is electricity from renewable energy sources that emit no $\mathrm{CO}_{2}$ during the conversion process. Each country has another electricity mix and, therefore, another carbon dioxide emission factor (IEA 2013). In Germany and the European Union, it is expected that $\mathrm{CO}_{2}$ emissions are reduced significantly until 2030 (Heinrichs 2013). However, the corresponding emissions might differ during the day due to a change in this mix. Therefore, our analysis on driving distances and parking times and the corresponding charging processes would be helpful for further analyses. Here, we would rather calculate two scenarios for the $\mathrm{CO}_{2}$ emissions from electricity. The first assumes that the electricity consumed by BEV would be generated emission free; the second scenario assumes average-specific $\mathrm{CO}_{2}$ emission values for Germany in 2012.

Hence, the calculation of the yearly total $\mathrm{CO}_{2}$ emissions reduction by commercial electric LCV is done with following formula.

$E_{\mathrm{red}}=n \times d \times\left(e_{\mathrm{ICEV}}-e_{\mathrm{BEV}}\right)$

- $E_{\text {red }}$ total annual $\mathrm{CO}_{2}$ emissions reduction in $\mathrm{t}_{\mathrm{CO}_{2}}$,

- $n$ number of potential electric vehicles, 
- $d$ average annual mileage with $30,603 \mathrm{~km}$ in the postal services,

- $e_{\mathrm{ICEV}}$ specific $\mathrm{CO}_{2}$ emissions of ICEV in $\mathrm{g}_{\mathrm{CO}_{2}} / \mathrm{km}$,

- $e_{\mathrm{BEV}}$ specific $\mathrm{CO}_{2}$ emissions of $\mathrm{BEV}$ in $\mathrm{g}_{\mathrm{CO}_{2}} / \mathrm{km}$.

For our analysis, we take the official values, for an example, vehicle (Mercedes-Benz Vito) that is available as conventional and electric version. The conventional Vito 110 CDI emits $211 \mathrm{~g}_{\mathrm{CO}_{2}} / \mathrm{km}$, whereas the Vito E-Cell consumes $25.2 \mathrm{kWh} / 100 \mathrm{~km}$ (Daimler 2013). In the first scenario, the corresponding $\mathrm{CO}_{2}$ emissions with "green" electricity amount to optimistic $0 \mathrm{~g} / \mathrm{km}$. For the second scenario, we assumed specific $\mathrm{CO}_{2}$ emissions of the electricity production in Germany of $576 \mathrm{~g}_{\mathrm{CO}_{2}} / \mathrm{kWh}$ (UBA 2013) which results in emissions of $145 \mathrm{~g}_{\mathrm{CO}_{2}} / \mathrm{km}$. Therefore, our calculation with $105,550 \mathrm{LCV}$ leads to an annually reduction of $\mathrm{CO}_{2}$ emissions of about 882,000 tonnes for the first scenario and to about 213,000 tonnes for the second scenario. This is about $40-70 \%$ in the postal services sector but still $<1 \%$ from the $\mathrm{CO}_{2}$ emissions from German road transport.

Despite these optimistic numbers for a high penetration of BEV for LCV in the postal services, the share of BEV in commercial use is still marginal. The development is, however, promising, as several companies from different sectors take part in research projects focusing on increasing the EV share in company fleets. Additionally, in the next years, several BEV models of established German vehicle manufacturers will be launched. The real substitution potential might be different from our calculations, as we had to make several assumptions. For example, we make the assumption that the vehicles can be charged in any case if they are parked at the own company or at a private place which might not be true. The assumed $150 \mathrm{~km}$ of electric range for electric $\mathrm{LCV}$ is also optimistic for now. But in near future, the range might be higher, as first BEV show. We also did not consider PHEV as the electric share of driven kilometers is highly speculative. The most relevant restriction is the data basis of KiD 2010 study. The study only includes mobility behavior of $24 \mathrm{~h}$ of each vehicle. Therefore, it is not possible to deduce from daily mileage the yearly mileage of single vehicles. And it is also not possible to evaluate mobility behavior changes during the week.

\section{Conclusion}

In order to make road transport to contribute to decreasing $\mathrm{CO}_{2}$ emissions-like other sectors-an electrification of the drive chain seems to be a promising technology. Today, however, the vehicle prices and the limited range make their field of application challenging. We identified by a bottom-up approach some profitable applications for LCV in German commercial transport, where ICEV could be replaced by $\mathrm{BEV}$. These user patterns fulfill already today all the requirements of $\mathrm{BEV}$ and could be operated by lower costs. Depending on the current electricity generation mix, the $\mathrm{CO}_{2}$ mitigation potential is already today about $40-70 \%$ the $\mathrm{CO}_{2}$ emissions from LCV in commercial transport of postal services (i.e., about 882,000 tonnes per year) - the future potential seems to be significantly higher.

Moreover, the results of the other generally analyzed sectors allow a first positive and descriptive identification for a rising distribution of $\mathrm{BEV}$ in commercial transport. Even though the operation range of $\mathrm{BEV}$ cannot compete with ICEV, the daily range of many vehicles is still below the current range of BEV. Another important indicator is the annual mileage which is relatively high in several economic sectors. Due to low operating costs and high annual mileages, a cost advantage for BEV compared to ICEV can be achieved for many applications. We identify that the differences in sectors are manifold, and therefore, it is necessary to further analyze the single economic sectors or clusters with the available fleet data. For the postal services, we identify an optimistic substitution potential of up to more than 60 or 106 thousand LCV based on the most restricting criteria, the charging infrastructure availability, and daily mileage. The current point in time seems promising for substituting ICEV by EV. Politics should support this process by setting the right incentives which seem, however, challenging as the transport participants react highly diverse (e.g., Alam et al. 2013; Bertoldi et al. 2011).

Further research is seen in collecting more detailed data for the heterogeneous trip patterns in different economic sectors. Such a dataset would improve the estimation of the substitution potential significantly. Furthermore, a more detailed analysis on the corresponding $\mathrm{CO}_{2}$ emissions during charging times by considering the corresponding electricity mix is another challenging research issue. Last but not least, the corresponding grid infrastructure should be compliant with these charging processes. The grid in some industrial areas might be stressed significantly. This has already been analyzed for residential areas by other authors (e.g., Paetz et al. 2013; Wairaich et al. 2013).

Acknowledgments This research is part of the project iZEUS (01ME12013) which is funded by the German Federal Ministry for Economic Affairs and Energy (BMWi).

\section{References}

Abt D (1998) Die Erklärung der Technikgenese des Elektroautomobils. Dissertation, University of Frankfurt (Main), Germany 
Al-Alawi BM, Bradley TH (2013) Total cost of ownership, payback, and consumer preference modeling of plug-in hybrid electric vehicles. Appl Energ 103:488-506. doi:10.1016/j.apenergy. 2012.10.009

Alam JB, Wadud Z, Polak W (2013) Energy demand and economic consequences of transport policy. Int $\mathrm{J}$ Environ Sci Technol 10:1075-1082. doi:10.1007/s13762-013-0240-1

Amjad S, Neelakrishnan S, Rudramoorthy R (2010) Review of design considerations and technological challenges for successful development and deployment of plug-in hybrid electric vehicles. Renew Sustain Energ Rev 14:1104-1110. doi:10.1016/j.rser.2009.11.001

B.A.U.M. (2012) Ergebnisbericht zum Förderprogramm IKT für Elektromobilität. German Federal Ministry of Economics and Technology, Berlin, Germany

BBSR (2011) Laufende Raumbeobachtung - Raumabgrenzungen. German Federal Institute for Research on Building, Urban Affairs and Spatial Development, Berlin, Germany

Berg MR (1985) The potential market for electric vehicles: results from a national survey of commercial fleet operators. Transport Res Rec 1049:70-78

Bertoldi P, Rezessy S, Anable J, Jochem P, Oikonomou V (2011) Energy saving obligations and white certificates: ideas and considerations for the transport sector. Int J Sustain Transp 5(6):345-374. doi:10.1080/15568318.2010.545472

BMVBS (2011a) Ergebnisbericht 2011 der Modellregionen Elektromobilität. German Federal Ministry of Transport, Building and Urban Development, Berlin, Germany

BMVBS (2011b) Verkehr in Zahlen 2010/2011. German Federal Ministry of Transport, Building and Urban Development, Berlin, Germany

BMWi (2008) Dienstleistungsverkehr in industriellen Wertschöpfungsketten-final report. German Federal Ministry of Economics and Technology, Berlin, Germany

BMWi (2012) Regierungsprogramm Elektromobilität - Übersicht zu umgesetzten oder initiierten Maßnahmen. German Federal Ministry of Economics and Technology, Berlin, Germany

Brauner G, Geringer B, Schrödl M (2012) Forschungsbedarf für das Elektrofahrzeug der Zukunft. e \& i. Elektrotechnik und Informationstechnik 129:110-117. doi:10.1007/s00502-012-0088-y

Daimler (2013) Verbrauchs- und Emissionswerte des Vito 110 CDI. http://www.mercedes-benz.de. Accessed 5 December 2013

DATELINE (2004) Design and application of a travel survey for European long-distance trips based on an international network of expertise (dateline). Institute for Transport Planning and Systems, Zurich, Switzerland

Deneke K (2004) Nutzungsorientierte Fahrzeugkategorien im Straßenwirtschaftsverkehr - Eine multidimensionale Analyse kraftfahrzeugbezogener Mobilitätsstrukturen. Dissertation, Technical University of Braunschweig, Germany

Destatis (2008) Klassifikation der Wirtschaftszweige. German Federal Statistical Office, Wiesbaden, Germany

Ensslen A, Jochem P, Schäuble J, Babrowski S, Fichtner W (2013) User acceptance of electric vehicles in the French-German transnational context. In: Selected proceedings of the 13th WCTR, Rio de Janeiro, Brazil 15-18 July

European Commission (2011) A Roadmap for moving to a competitive low carbon economy in 2050. European Commission, Brussels

European Commission (2012) EU transport in figures-statistical pocketbook 2012. European Commission, Luxembourg

Eurostat (2008) NACE Rev. 2-statistical classification of economic activities in the European Community. European Commission, Brussels, Belgium

Eurostat (2012) Energy statistics-prices. European Commission, Brussels

Eurostat (2013) Greenhouse gas emissions by sector. European Commission, Brussels
Feng W, Figliozzi MA (2012) Conventional vs. electric commercial vehicle fleets: a case study of economic and technological factors affecting the competitiveness of electric commercial vehicles in the USA. Procedia Soc Behav Sci 39:702-711. doi:10.1016/j. sbspro.2012.03.141

Figliozzi MA, Boudart JA, Feng W (2011) Economic and environmental optimization of vehicle fleets. Transp Res Rec 2252:1-6. doi: $10.3141 / 2252-01$

German Federal Government (2009) Nationaler Entwicklungsplan Elektromobilität der Bundesregierung. German Federal Government, Berlin

German Federal Government (2010) Energiekonzept für eine umweltschonende, zuverlässige und bezahlbare Energieversorgung. German Federal Government, Berlin

Gnann T, Haag M, Plötz P, Wietschel M (2013) Market potential for electric vehicles in the German commercial passenger transport sector. In: Proceedings of EVS27 International Battery, Hybrid and Fuel Cell Electric Vehicle Symposium, Barcelona, Spain 17-20 November

Hacker F, Harthan R, Hermann H, Kasten P, Loreck C, Seebach D, Timpe C, Zimmer W, Leppler S, Möck A (2011) Betrachtung der Umweltentlastungspotenziale durch den verstärkten Einsatz von kleinen, batterieelektrischen Fahrzeugen im Rahmen des Projekts 'E-Mobility' - Schlussbericht. Oeko-Institut e.V., German Federal Ministry of Transport, Building and Urban Development, Freiburg and Berlin, Germany

Hautzinger H, Stock W, Mayer K, Schmidt J, Heidemann D (2005) Fahrleistungserhebung 2002 - Inländerfahrleistung. Wirtschaftsverlag NW, Bremen

Hebes P (2011) Die Rolle von Unternehmen beim Verkehrsverhalten im Personenwirtschaftsverkehr. Dissertation, Humbold University of Berlin, Germany

Heinrichs HU (2013) Analyse der langfristigen Auswirkungen von Elektromobilität auf das deutsche Energiesystem im europäischen Energieverbund. KIT Scientific Publishing, Karlsruhe

Hu PS, Reuscher TR (2004) Summary of travel trends-2001 national household travel survey. http://nhts.ornl.gov/2001/pub/STT.pdf. Accessed 25 March 2013

ICCT (2013) Reducing $\mathrm{CO}_{2}$ and fuel consumption: a summary of the technology potential for new cars in the EU, International Council on Clean Transportation

IEA (2009) Technology roadmap: electric and plug-in hybrid electric vehicles. International Energy Agency, Paris

IEA (2011) Technology roadmap-electric and plug-in hybrid electric vehicles. International Energy Agency, Paris

IEA (2013) World energy outlook 2013, international energy agency. France, Paris

IKA (2012) $\mathrm{CO}_{2}$-Reduzierungspotenziale bei Pkw bis 2020. Institut für Kraftfahrzeuge, Strategie und Beratung, RWTH Aachen University, Germany

Kaschub T, Paetz AG, Jochem P, Fichtner W (2012) Feasibility of battery switch stations for local emission free public transport. In: ENERDAY 7th Conference on Energy Economics and Technology, Dresden, Germany

Kay D, Hill N, Newman D (2013) Powering Ahead-The future of low-carbon cars and fuels. UK Petroleum Industry Association. http://www.theengineer.co.uk/Journals/2013/04/22/i/k/h/powering ahead-kay_et_al-apr.2013-embargoed_copy.pdf. Accessed 30 November 2013

KBA (2010) Verkehr deutscher Lastkraftfahrzeuge (VD) Güterbeförderung. German Federal Motor Transport Authority, Flensburg, Germany

KBA (2011) Fahrzeugzulassungen (FZ) - Bestand an Kraftfahrzeugen und Kraftfahrzeuganhängern nach Haltern und Wirtschaftszweigen. German Federal Motor Transport Authority, Flensburg, Germany 
KBA (2013) Der Fahrzeugbestand im Überblick am 1. Januar 2013 gegenüber 1. Januar, 2012. German Federal Motor Transport Authority, Flensburg, Germany

KiD (2003) Kraftfahrzeugverkehr in Deutschland-KiD 2002-final report. German Federal Motor Transport Authority, Flensburg, Germany

KiD (2012a) Kraftfahrzeugverkehr in Deutschland 2010-KiD 2010-final report. German Federal Ministry of Transport, Building and Urban Development, Berlin, Germany

KiD (2012b) Kraftfahrzeugverkehr in Deutschland 2010-KiD 2010-Ergebnisse im Überblick. German Federal Motor Transport Authority, Flensburg, Germany

Kley F (2011) Ladeinfrastrukturen für Elektrofahrzeuge - Entwicklung und Bewertung einer Ausbaustrategie auf Basis des Fahrverhaltens. Dissertation. Karlsruhe Institute of Technology, Germany

Köhler U (2009) Applications-transportation-hybrid electric vehicles: batteries. In: Garche J (ed) Encyclopedia of electrochemical power sources. Elsevier, Amsterdam, pp 269-285

Liao CH, Chang CL, Su CY, Chiueh PT (2013) Correlation between land-use change and greenhouse gas emissions in urban areas. Int J Environ Sci Techno. 10:1275-1286. doi:10.1007/s13762$012-0155-2$

Ligterink NE, Smokers RTM, Bolech M (2013) Fuel-electricity mix and efficiency in Dutch plug-in and range-extender vehicles on the road. In: Proceedings of EVS27 International Battery, Hybrid and Fuel Cell Electric Vehicle Symposium, Barcelona, Spain 17-20 November

Machledt-Michael S (2000) Fahrtenkettenmodell für den städtischen und regionalen Wirtschaftsverkehr, Dissertation, Technical University of Braunschweig, Germany

Madre JL, Kuhnimhof T, Armoogum J, Last J, Sender, F (2007) Deliverable d3 existence and comparability of data sources. Institut National de Recherche sur les Transports et leur Securite and STRATA GmbH - Data and Information Management, Paris and Karlsruhe, France and Germany

Menge J (2011) Personenwirtschaftsverkehr im Prozess der Dienstleistungserstellung -Ursachen, Strukturen und räumliche Muster. Dissertation, Humbold University of Berlin, Germany

MiD (2010) Mobilität in Deutschland 2008 - Kurzbericht - Struktur Aufkommen - -Emissionen - Trends. German Federal Ministry of Transport, Building and Urban Development, Berlin, Germany

Mock P (2010) Entwicklung eines Szenariomodells zur Simulation der zukünftigen Marktanteile und CO2-Emissionen von Kraftfahrzeugen (VECTOR21). Dissertation, University of Stuttgart, Germany

NIST (2009) Nist framework and roadmap for smart grid interoperability standards. National Institute of Standards and Technology, Gaithersburg

NPE (2010) Zwischenbericht der Nationalen Plattform Elektromobilität. National Platform for Electromobility, Berlin

NPE (2011) Zweiter Bericht der Nationalen Plattform Elektromobilität. National Platform for Electromobility, Berlin

NPE (2012) Fortschrittsbericht der Nationalen Plattform Elektromobilität (Dritter Bericht). National Platform for Electromobility, Berlin

OECD (2012) Transport outlook 2012. Organization for Economic Co-operation and Development, Paris

Paetz AG, Kaschub T, Kopp M, Jochem P, Fichtner W (2013) Monetäre Anreize zur Steuerung der Ladelast von Elektrofahrzeugen - eine modellgestützte Optimierung. Zeitschrift für Energiewirtschaft 37:1-12. doi:10.1007/s12398-012-0095-z

Parker C (2009) Batteries-codes and standards. In: Garche J (ed) Encyclopedia of electrochemical power sources. Elsevier, Amsterdam, pp 539-543
Pehnt M, Helms H, Lambrecht U, Dallinger D, Wietschel M, Heinrichs H, Kohrs R, Link J, Trommer S, Pollok T, Behrens P (2011) Elektroautos in einer von erneuerbaren Energien geprägten Energiewirtschaft. Zeitschrift für Energiewirtschaft 35:221-234. doi:10.1007/s12398-011-0056-y

Pfahl S, Jochem P, Fichtner W (2013) When will Electric Vehicles Capture the German Market? And Why? In: Proceedings of EVS27 International Battery, Hybrid and Fuel Cell Electric Vehicle Symposium, Barcelona, Spain 17-20 November

Plötz P, Gnann T, Wietschel M (2012) Total ownership cost projection for the German electric vehicle market with implications for its future power and electricity demand. In: ENERDAY 7th Conference on Energy Economics and Technology, Dresden, Germany 27 April

Pregger T, Tena DL, O’Sullivan M, Roloff N, Schmid S, Propfe B, Hülsebusch D, Wille-Haussmann B, Schwunk S, Wittwer C, Pollok T, Krahl S, Moormann A (2012) Perspektiven von Elektro-/Hybridfahrzeugen in einem Versorgungssystem mit hohem Anteil dezentraler und erneuerbarer Energiequellen. German Federal Ministry of Economics and Technology, Berlin

Proff H, Kilian D (2012) Competitiveness of the EU automotive industry in electric vehicles. University of Duisburg-Essen, Duisburg

RITA (2010) Freight transportation: global highlights 2010. US Department of Transportation, Washington

Santos A, McGuckin N, Nakamoto HY, Gray D, Liss S (2011) Summary of travel trends-2009 national household travel survey. US Department of Transportation, Washington

Schütte FP (1995) Mobilitätsprofile im städtischen Personenwirtschaftsverkehr. Dissertation, University of Dortmund, Germany

Schwerdtfeger W (1976) Städtischer Lieferverkehr: Bestimmungsgründe, Umfang und Ablauf des Lieferverkehrs von Einzelhandels- und Dienstleistungsbetrieben. Dissertation, Technical University Braunschweig. Germany

Sharma R, Manzie C, Bessede M, Brear MJ, Crawford RH (2012) Conventional, hybrid and electric vehicles for australian driving conditions-part 1: technical and financial analysis. Transport Res C Emerg 25:238-249. doi:10.1016/j.trc.2012.06.003

Steinmeyer I (2004) Zur Datenlage und Notwendigkeit der Modellierung von Wirtschaftsverkehr in Städten und Regionen. In: 1. Europäisches Kommunalpolitisches Verkehrsforum - Wirtschaftsverkehr in Städten - Wege aus der Krise. German Association of Transport Sciences, Berlin, Germany

UBA (2013) Entwicklung der spezifischen Kohlendioxid-Emissionen des deutschen Strommix in den Jahren 1990 bis 2012. Federal Environment Agency, Dessau-Roßlau

UN (1998) The kyoto protocol to the United Nations framework convention on climate change (UNCCC). United Nations, Kyoto

UN (2008) International standard industrial classification of all economic activities (isic) Rev. 4. United Nations, New York, USA

Uslar M, Beenken P, Busemann C, Gonzáles JM, Kamenik J, Mayer C, Niesse A, Rohjans S, Schmedes T, Specht M, Weidelt T, Schwarz K, Hein F (2009) Untersuchung des Normungsumfeldes zum BMWi-Förderschwerpunkt "e-Energy - IKT-basiertes Energiesystem der Zukunft". German Federal Ministry of Economics and Technology, Berlin

Uslar M, Rohjans S, Gonzalez J, Specht M, Trefke J (2011) Das Standardisierungsumfeld im Smart Grid - Roadmap und Outlook. e\&i. Elektrotechnik und Informationstechnik 128:135-140. doi:10.1007/s00502-011-0818-6

van Dender K (2009) Energy policy in transport and transport policy. Energ Policy 37:3854-3862. doi:10.1016/j.enpol.2009.07.008

van Vliet O, Brouwer AS, Kuramochi T, van den Broek M, Faaij A (2011) Energy use; cost and $\mathrm{CO}_{2}$ emissions of electric cars. 
J Power Sources 196:2298-2310. doi:10.1016/j.jpowsour.2010. 09.119

Wairaich RA, Galus MD, Dobler C, Balmer M, Andersson G, Axhausen KW (2013) Plug-in hybrid electric vehicles and smart grids: investigations based on a microsimulation. Transport Res C Emerg 28:74-86. doi:10.1016/j.trc.2012.10.011

Walvekar PP, Gurjar BR (2012) Formulation, application and evaluation of a stack emission model for coal-based power stations. Int J Environ Sci Technol. doi:10.1007/s13762-0120131-x
Wermuth M (2006) Der Wirtschaftsverkehr auf Deutschlands Straßen - Stimmen unsere bisherigen Vermutungen? Straßenverkehrstechnik 50:5-14

WTO (2012) International trade statistics 2012. World Trade Organization, Geneva

Zumkeller D, Kagerbauer M, Streit T, Vortisch P, Chlond B, Wirtz M (2011) Deutsches Mobilitätspanel (MOP) wissenschaftliche Begleitung und erste Auswertungen - Bericht 2011: Alltagsmobilität \& Tankbuch. Karlsruhe Institute of Technology, Karlsruhe 